\title{
PROSES SELEKSI LOKASI PADA PROGRAM PEMBERDAYAAN KELOMPOK SADAR WISATA DI KOTA DEPOK
}

\author{
Adita Maya Safira ${ }^{1}$, Susie Perbawasari ${ }^{2}$, Anwar Sani $^{3}$ \\ ${ }^{1,2,3}$ Fakultas Ilmu Komunikasi, Program Studi Hubungan Masyarakat, Universitas Padjadjaran \\ Jl. Raya Bandung-Sumedang KM 21, Jatinangor, Kab. Sumedang, Jawa Barat, 45363, Indonesia \\ No. Telp./HP: ${ }^{1} 081291716486,{ }^{2} 0811214790,{ }^{3} 081221114401$ \\ E-mail: ${ }^{1}$ aditamayasafira@gmail.com, ${ }^{2}$ susie.perbawasari@yahoo.com, ${ }^{3}$ anwar.sani@unpad.ac.id
}

Naskah diterima tanggal 25 Juni 2017, direvisi tanggal 2 Februari 2018, disetujui tanggal 23 Maret 2018

\section{LOCATION SELECTION PROCESS ON EMPOWERMENT PROGRAM KELOMPOK SADAR WISATA IN DEPOK CITY}

\begin{abstract}
Tourism becomes one opportunity for City of Depok to increase local revenue. Therefore, Disporaparsenbud finds it necessary to preserve it by doing community empowerment by creating Kelompok Sadar Wisata empowerment program. However, the program undertook by Disporaparsenbud is considered to have a weakness at the stage of location selection. This study aims to determine the criteria and involvement of related parties in the process of location selection on Kelompok Sadar Wisata empowerment program as one activity of community empowerment by Disporaparsenbud City of Depok. The research method used is a qualitative descriptive. Data collection is done by observation, interview, and literature study. The results show that the location selection is done by determining the criteria, the criteria are retribution and region potency, but there is no agreement with the stakeholders. The communication context of the selection process of location/region is classified into the context of group communication and interpersonal communication, the community becomes the important element alongside with the government and the private sector to implement and support the tourism development.
\end{abstract}

Keywords: selection area, community empowerment, kelompok sadar wisata, tourism.

\begin{abstract}
Abstrak. Pariwisata menjadi salah satu peluang bagi Kota Depok untuk meningkatkan pendapatan daerah. Untuk itu Disporaparsenbud Kota Depok merasa perlu untuk melestarikan situ dengan melakukan pemberdayaan masyarakat dengan membuat Program Pembinaan Kelompok Sadar Wisata. Namun, program yang dilakukan oleh Disporaparsenbud Kota Depok tersebut dianggap masih memiliki kekurangan yakni pada tahap seleksi lokasi. Penelitian ini bertujuan untuk mengetahui kriteria serta keterlibatan pihak terkait dalam proses seleksi lokasi pada program pembinaan Kelompok Sadar Wisata sebagai salah satu kegiatan pemberdayaan masyarakat oleh Disporaparsenbud Kota Depok. Metode penelitian yang digunakan adalah metode deskriptif kualitatif. Pengumpulan data dilakukan dengan cara observasi, wawancara, dan studi pustaka. Hasil penelitian menunjukkan bahwa seleksi lokasi dilakukan dengan cara menetapkan kriteria, kriteria tersebut adalah retribusi dan potensi wilayah, namun tidak ada kesepakatan dengan para pemangku kepentingan. Konteks komunikasi dari proses seleksi lokasi/wilayah ini tergolong ke dalam konteks komunikasi kelompok dan komunikasi antarpribadi, masyarakat menjadi salah satu unsur penting untuk bersama-sama dengan pemerintah dan swasta melaksanakan dan mendukung pembangunan kepariwisataan.
\end{abstract}

Kata kunci: seleksi lokasi, pemberdayaan masyarakat, kelompok sadar wisata, pariwisata. 


\section{PENDAHULUAN}

Kota Depok merupakan kota yang berada di perbatasan antara Kota Jakarta dan Kota Bogor, sehingga menjadi salah satu kota transit yang memiliki permukiman padat penduduk. Dengan kepadatan penduduk yang tinggi tentu saja Kota Depok perlu mencari peluang untuk memperoleh pendapatan daerah guna terciptanya daerah yang nyaman bagi penduduk dan juga mampu memperbaiki prasarana yang ada di Kota Depok. Salah satu aspek yang dapat dijadikan peluang bagi Kota Depok adalah dari segi pariwisata.

Jumlah situ yang ada di Kota Depok tidak bisa dipastikan, dikarenakan banyaknya situ yang hilang karena tidak dirawat, sehingga terjadi pedangkalan dan adapula yang sudah beralih fungsi. Pengalihan fungsi situ dan pembangunan baik untuk permukiman maupun kepentingan lainnya di atas lahan situ menjadi isu yang mengkhawatirkan. Berbagai kepentingan pribadi dan ketidakpedulian terhadap situ yang bisa menjadi aset pariwisata Kota Depok telah menyebabkan beberapa situ tidak bisa dipertahankan dan akhirnya hilang. Salah satu contohnya yaitu Situ Pasir Putih di Kecamatan Sawangan.

Kota Depok memiliki banyak situ yang dapat menjadi potensi daya tarik wisata dan itulah yang harus dikembangkan demi mencapai Depok sebagai tujuan wisata. Hal tersebut dapat dicapai jika Kota Depok dapat mengembangkan potensi wisata situ tersebut, sehingga dapat mengembangkan potensi pariwisata air. Untuk mencapai pengembangan potensi wisata air khususnya situ, tidak dapat dilakukan sekaligus untuk seluruh situ, melainkan perlu dilakukan secara bertahap. Untuk itu Dinas Pemuda Olahraga Pariwisata Seni dan Budaya Kota Depok perlu melakukan seleksi lokasi/wilayah dari seluruh situ yang ada di Kota Depok. Seleksi wilayah perlu dilakukan untuk memilih lokasi mana yang cocok untuk diberikan kegiatan pemberdayaan masyarakat.

Guna mencapai pembangunan pariwisata Kota Depok ini, salah satunya dengan melakukan pemberdayaan masyarakat yang berada di sekitar objek wisata dengan membentuk Kelompok Sadar Wisata (Pokdarwis). Demi mendukung berlangsungnya programprogram dari Kelompok Sadar Wisata ini, Dinas Pemuda Olahraga Pariwisata Seni dan Budaya (Disporaparsenbud) Kota Depok melakukan program pembinaan Kelompok Sadar Wisata dalam upaya mengembangkan pariwisata Kota Depok dengan memberdayakan masyarakat yang tinggal di sekitar objek wisata.

Menurut Munir, "Enam pokdarwis yang telah diberikan pengukuhan yaitu Pokdarwis Situ Sawangan, Situ Jatijajar, Situ Sidumukti, Situ Pedongkelan, Situ Pulo Asih dan Situ Cilodong. Sedangkan tiga Situ yang akan segera dikukuhkan Pokdarwis yakni, Situ Lio, Situ Citayem dan Situ Pengasinan" (Depoktren, 2014).

Program-program yang dilakukan oleh kelompok sadar wisata secara garis besar adalah menjaga kelestarian dan keutuhan situ, meningkatkan fungsi situ sebagai sumber penampungan air, dan memanfaatkan situ untuk kepentingan masyarakat dengan cara pemeliharaan ikan dan objek serta prasarana pariwisata. Pokdarwis juga aktif dalam mengelola sarana permainan air yang disediakan oleh Disporarsenbud. Adapun kegiatan yang dilakukan oleh ibu-ibu pokdarwis ialah dengan membuka usaha dan berdagang di sekitar objek wisata situ.

Program Pembinaan Kelompok Sadar Wisata oleh Disporaparsenbud Kota Depok ini hanya dilakukan untuk objek wisata situ atau yang lebih dikenal dengan danau. Pemberdayaan masyarakat di sekitar objek wisata oleh Disporaparsenbud Kota Depok ini dilakukan agar mereka mampu secara mandiri mengelola objek wisata tersebut yang nantinya akan berdampak pada peningkatan kunjungan wisatawan dan 
kesejahteraan masyarakat di sekitar objek wisata. Sayangnya, Program Pembinaan Kelompok Sadar Wisata yang dilakukan oleh Disporaparsenbud Kota Depok ini masih dianggap kurang optimal oleh kelompok sadar wisata. Hal tersebut dikarenakan Disporaparsenbud Kota Depok langsung menyeleksi 10 situ dari total 22 situ yang ada di Kota Depok untuk mendapatkan Program Pembinaan Kelompok Sadar Wisata tanpa membuat kesepakatan dengan kelompok sadar wisata. Adapun 10 situ yang terpilih adalah Situ Sawangan, Situ Jatijajar, Situ Sidamukti, Situ Pedongkelan, Situ Pulo Asih atau Situ Asih, Situ Cilodong, Situ Lio, Situ Citayem, Situ Cilangkap, dan Situ Pengasinan

Berdasarkan uraian di atas, perlu ada penelitian terkait dengan seleksi lokasi pada Program Pembinaan Kelompok Sadar Wisata yang merupakan salah satu tahapan kegiatan pemberdayaan masyarakat (community empowerment) Dinas Pemuda Olahraga Pariwisata Seni dan Budaya Kota Depok dalam upaya mengembangkan pariwisata Kota Depok serta konteks komunikasi dalam seleksi lokasi.

\section{LANDASAN KONSEP}

\section{Review Penelitian Sejenis}

Irawan (2013) melalui tesisnya yang berjudul Corporate Social Responsibility (CSR) Berbasis Pemberdayaan Masyarakat, mengkaji mengenai program kawasan sehat mandiri konsep biomethagreen yang merupakan CSR dari PT. PLN (Persero) Distribusi Jawa Barat dan Banten (DJBB). Fokus dari penelitian tersebut yaitu untuk mengetahui latar belakang dan motif program CSR, mengetahui implementasi program CSR, mengetahui respon dan partisipasi masyarakat terhadap program CSR yang dilaksanakan oleh PT. PLN (Persero) DJBB ini. Penelitian tersebut menggunakan teori legitimasi, teori stakeholder, dan teori interaksi simbolik.
Metode penelitian yang digunakan adalah kualitatif dengan pendekatan studi kasus. Teknik pengumpulan data melalui wawancara mendalam, observasi, dan studi kepustakaan. Hasil penelitian menunjukkan bahwa latar belakang program CSR ini yaitu keprihatinan PT. PLN (Persero) DJBB terhadap isu planet, profit, dan people, kemudian motifnya sendiri yaitu motif kewajiban moral, izin operasi, reputasi, dan keberlanjutan. Implementasi program CSR ini melalui strategi kombinasi (mixed type), dimana PT. PLN (Persero) DJBB melibatkan masyarakat serta berbagai stakeholder dalam pelaksanaannya. Respon dan partisipasi masyarakat terhadap program CSR ini sangat positif.

Sari (2014) dalam skripsinya yang berjudul Program Pemberdayaan Kontraktor Lokal Total E\&P Indonesie, mengkaji mengenai latar belakang dan pelaksanaan program pemberdayaan kontraktor lokal sebagai salah satu kegiatan community development TOTAL E\&P Indonesia (TEPI), serta pemahaman program tersebut oleh tim SDS/EKS/CER selaku pelaksana dari program dan kontraktor lokal selaku peserta program. Teori yang digunakan dalam penelitian ini adalah teori konstruksi sosial atas Realitas oleh Peter L. Berger. Metode yang digunakan yaitu metode kualitatif dengan pendekatan studi kasus. Pengumpulan data dilakukan dengan observasi, wawancara, dokumentasi, dan studi pustaka. Hasil penelitian menunjukkan bahwa TEPI membuat Program Pemberdayaan Kontraktor Lokal atas dasar keinginan untuk melindungi wilayah operasional perusahaan akibat adanya gejolak sosial yang ada di masyarakat.

\section{Community Development}

Pengembangan masyarakat dapat didefinisikan sebagai "Kegiatan pengembangan masyarakat yang diarahkan untuk memperbesar akses masyarakat untuk mencapai kondisi sosial-ekonomibudaya yang lebih baik apabila 
dibandingkan dengan kegiatan pembangunan sebelumnya" (Rudito \& Budimanta, 2003). Secara hakikat, community development merupakan suatu proses adaptasi sosial budaya yang dilakukan oleh industri, pemerintah pusat dan daerah terhadap kehidupan komunitas lokal (Rudito \& Famiola, 2013).

Community development atau pengembangan masyarakat bukan berpijak pada pertolongan (to help), melainkan harus berpijak pada prinsip pemberdayaan (to empowerment). Community development melibatkan interaksi dinamis dan parsipatoris antar beragam stakeholders, termasuk "pihak luar" dan warga setempat (Suharto, 2010). Community development mengekspresikan nilai-nilai keadilan, kesetaraan, akuntabilitas, kesempatan, pilihan, partisipasi, kerjasama, dan proses belajar yang berkelanjutan. Pendidikan, pendampingan, dan pemberdayaan adalah inti dari community development. Community development berkenaan dengan bagaimana memengaruhi struktur dan relasi kekuasaan untuk menghilangkan hambatan-hambatan yang mencegah orang berpartisipasi dalam kegiatan-kegiatan yang memengaruhi kehidupan mereka (Suharto, 2010).

Menurut Suharto (2010), tujuan utama dari community development adalah memberdayakan individu-individu dan kelompok-kelompok orang melalui penguatan kapasitas (termasuk kesadaran, pengetahuan, dan keterampilanketerampilan) yang diperlukan untuk mengubah kualitas kehidupan komunitas mereka.

Lebih lanjut menurut (Rudito \& Famiola, 2013), community development sebagai wadah program yang berguna untuk menciptakan kemandirian komunitas lokal untuk menata sosial ekonomi mereka sendiri. Tujuan community development memperlihatkan bagaimana anggota masyarakat dapat mengaktualisasikan diri mereka dalam pengelolaan lingkungan yang ada di sekitarnya dan memenuhi kebutuhan secara mandiri tanpa ketergantungan dengan pihak-pihak lain, dan tentunya dengan menggunakan dasar budaya yang telah diterima secara turun temurun.

\section{Community Empowerment}

Secara umum, ruang lingkup program-program community development dapat dibagi berdasarkan tiga kategori yang secara keseluruhan akan bergerak secara bersama-sama, ketiga kategori tersebut adalah: (1) Community relations yaitu kegiatan-kegiatan yang menyangkut pengembangan kesepahaman melalui komunikasi dan informasi kepada para pihak yang terkait; (2) Community services, merupakan pelayanan perusahaan untuk memenuhi kepentingan masyarakat ataupun kegiatan umum, dan (3) Community empowerment, merupakan program-program yang berkaitan dengan memberikan akses yang lebih luas kepada masyarakat untuk menunjang kemandiriannya, seperti pembentukan koperasi ataupun usaha kecil lainnya yang secara natural anggota masyarakat sudah mempunyai pranata pendukungnya dan perusahaan hanya memberikan akses kepada pranata sosial yang ada tersebut agar berlanjut (Rudito \& Famiola, 2013).

Menurut Jerold dalam Iriantara (2004), community relations didefinisikan sebagai peningkatan partisipasi dan posisi organisasi di dalam sebuah komunitas melalui berbagai upaya untuk kemaslahatan bersama bagi organisasi dan komunitas.

Menurut Sumodiningrat dalam Mardikanto \& Soebiato (2012), pemberdayaan merupakan upaya pemberian kesempatan dan/atau memfasilitasi kelompok miskin agar mereka memiliki aksesibilitas terhadap sumber daya, yang berupa: modal, teknologi, informasi, jaminan pemasaran, agar mereka mampu memajukan dan mengembangkan usahanya, sehingga memperoleh perbaikan pendapatan serta perluasan kesempatan kerja demi 
perbaikan

kehidupan

dan

kesejahteraannya.

Pemberdayaan dapat pula diartikan sebagai upaya memenuhi kebutuhan yang diinginkan oleh individu, kelompok, dan masyarakat luas agar mereka memiliki kemampuan untuk melakukan pilihan dan mengontrol lingkungannya agar dapat memenuhi keinginan-keinginannya, termasuk aksesibilitasnya terhadap sumber daya yang terkait dengan pekerjaannya (Mardikanto \& Soebiato, 2012).

Secara tersirat, pemberdayaan memberikan tekanan pada otonomi pengambilan keputusan dari suatu kelompok masyarakat, yang dilandasi dengan penerapan aspek demokratis, partisipasi dengan titik fokusnya pada lokalitas, sebab masyarakat akan merasa diberdayakan melalui isu-isu lokal (Mardikanto \& Soebiato, 2012).

Pemberdayaan

masyarakat merupakan upaya untuk meningkatkan harkat dan martabat lapisan masyarakat yang dalam kondisi sekarang tidak mampu untuk melepaskan diri dari perangkap kemiskinan dan keterbelakangan.

Menurut Sumodiningrat dalam Mardikanto \& Soebiato (2012), pemberdayaan masyarakat merupakan upaya untuk memandirikan masyarakat lewat perwujudan potensi kemampuan yang mereka miliki. Adapun pemberdayaan masyarakat senantiasa menyangkut dua kelompok yang saling terkait, yaitu masyarakat sebagai pihak yang diberdayakan dan pihak yang menaruh kepedulian. Mubyarto menekankan bahwa pemberdayaan terkait erat dengan pemberdayaan ekonomi rakyat (Mardikanto \& Soebiato, 2012).

\section{Tahapan Kegiatan Pemberdayaan Masyarakat}

Delivery dalam Mardikanto \& Soebiato (2012), menawarkan tahapantahapan kegiatan pemberdayaan masyarakat yang dimulai dari proses seleksi lokasi sampai dengan pemandirian masyarakat. Secara rinci masing-masing tahap tersebut adalah sebagai berikut:

Tahap 1. Seleksi lokasi

Seleksi wilayah dilakukan sesuai dengan kriteria yang disepakati oleh lembaga, pihak-pihak terkait dan masyarakat. Penetapan kriteria penting agar pemilihan lokasi dilakukan sebaik mungkin, sehingga tujuan pemberdayaan masyarakat akan tercapai seperti yang diharapkan.

Tahap 2. Sosialisasi pemberdayaan masyarakat

Sosialisasi merupakan upaya mengomunikasikan kegiatan untuk menciptakan dialog dengan masyarakat. Melalui sosialisasi akan membantu untuk meningkatkan pemahaman masyarakat dan pihak terkait tentang program dan/atau kegiatan pemberdayaan masyarakat yang telah direncanakan. Proses sosialisasi menjadi sangat penting, karena akan menentukan minat dan ketertarikan masyarakat untuk berpartisipasi (berperan dan terlibat) dalam program pemberdayaan masyarakat yang dikomunikasikan.

Tahap 3. Proses pemberdayaan masyarakat

Hakikat pemberdayaan masyarakat adalah untuk meningkatkan kemampuan dan kemandirian masyarakat dalam meningkatkan taraf hidupnya. Dalam proses tersebut masyarakat bersama-sama melakukan hal-hal berikut: 1) Kajian keadaan perdesaan partisipatif. Mengidentifikasi dan mengkaji potensi wilayah, permasalahan, serta peluangpeluangnya. Kegiatan ini dimaksudkan agar masyarakat mampu dan percaya diri dalam mengidentifikasi serta menganalisis keadaannya, baik potensi maupun permasalahannya; 2) Pengembangan kelompok. Menyusun rencana kegiatan kelompok, berdasarkan hasil kajian; 3) Penyusunan rencana dan pelaksanaan kegiatan. Menerapkan rencana kegiatan kelompok seperti rencana yang telah disusun bersama dengan dukungan fasilitasi dari pendamping, selanjutnya diimplementasikan dalam kegiatan yang konkrit dengan tetap memperhatikan 
realisasi dan rencana awal. Termasuk dalam kegiatan ini, adalah pemantauan pelaksanaan dan kemajuan kegiatan menjadi perhatian semua pihak, selain itu juga dilakukan perbaikan jika diperlukan; 4) Monitoring dan evaluasi partisipatif. Memantau proses dan hasil kegiatan secara terus menerus secara partisipatif (Participatory Monitoring dan Evaluation). Participatory Monitoring dan Evaluation ini dilakukan secara mendalam pada semua tahapan pemberdayaan masyarakat agar prosesnya berjalan sesuai dengan tujuannya. Participatory Monitoring dan Evaluation adalah suatu proses penilaian, pengkajian, dan pemantauan kegiatan, baik prosesnya (pelaksanaan) maupun hasil dan dampaknya agar dapat disusun proses perbaikan kalau diperlukan.

Tahap 4. Pemandirian masyarakat

$$
\text { Berpegang pada prinsip }
$$

pemberdayaan masyarakat yang bertujuan untuk memandirikan masyarakat dan meningkatkan taraf hidupnya, maka arah pemandirian masyarakat adalah berupa pendampingan untuk menyiapkan masyarakat agar benar-benar mampu mengelola sendiri kegiatannya.

Proses pemberdayaan masyarakat terkait erat dengan faktor internal dan eksternal. Dalam hubungan ini, meskipun faktor internal sangat penting sebagai salah satu wujud self organizing dari masyarakat, namun juga perlu diberikan perhatian pada faktor eksternalnya. Proses pemberdayaan masyarakat mestinya juga didampingi oleh suatu tim fasilitator yang bersifat multidisiplin. Tim pendamping ini merupakan salah satu external factor dalam pemberdayaan masyarakat. Peran tim pada awal proses sangat aktif tetapi akan berkurang secara bertahap selama proses berjalan sampai masyarakat sudah mampu melanjutkan kegiatannya secara mandiri.

Dalam operasionalnya inisiatif tim pemberdayaan masyarakat secara perlahan akan dikurangi dan akhirnya berhenti. Peran tim fasilitator akan dipenuhi oleh pengurus kelompok dan pihak lain yang dianggap mampu oleh masyarakat. Kapan waktu pemunduran tim fasilitator tergantung kesepakatan bersama yang telah ditetapkan sejak awal program dengan warga masyarakat.

\section{Pariwisata}

Pariwisata adalah segala kegiatan dalam masyarakat yang berhubungan dengan wisatawan. Semua kegiatan pembangunan hotel, pemugaran objek budaya, pembuatan pusat rekreasi, penyelenggaraan pekan pariwisata, penyediaan angkutan dan sebagainya dapat dikatakan sebagai kegiatan kepariwisataan sepanjang dengan kegiatan-kegiatan tersebut dapat mendatangkan wisatawan (Soekadijo, 2000).

Di dalam Undang-Undang Nomor 9 Tahun 1990 tentang Kepariwisataan (Republik Indonesia, 1990), menyatakan bahwa wisata adalah kegiatan perjalanan atau sebagian dari kegiatan tersebut dilakukan secara sukarela bersifat sementara untuk menikmati objek dan daya tarik wisata. Unsur pokok yang harus mendapat perhatian guna menunjang pengembangan pariwisata di daerah tujuan wisata yang menyangkut perencanaan, pelaksanaan pembangunan dan pengembangannya meliputi lima unsur:

- Objek dan daya tarik wisata,

- Prasarana wisata,

- Sarana wisata,

- Infrastruktur,

- Masyarakat/lingkungan.

\section{Kelompok Sadar Wisata}

Kegiatan

pembangunan kepariwisataan, sebagaimana halnya pembangunan di sektor lainnya, pada hakikatnya melibatkan peran dari seluruh pemangku kepentingan yang ada dan terkait. Pemangku kepentingan yang dimaksud meliputi tiga pihak yaitu: pemerintah, swasta, dan masyarakat, dengan segenap peran dan fungsinya masing-masing. Peningkatan peran masyarakat dalam pembangunan 
kepariwisataan memerlukan berbagai upaya pemberdayaan (empowerment), agar masyarakat dapat berperan lebih aktif dan optimal serta sekaligus menerima manfaat positif dari kegiatan pembangunan yang dilaksanakan untuk peningkatan kesejahteraannya.

Kelompok Sadar Wisata (Pokdarwis) merupakan salah satu komponen dalam masyarakat yang memiliki peran dan kontribusi penting dalam pengembangan kepariwisataan di daerahnya. Sadar wisata, adalah suatu kondisi yang menggambarkan partisipasi dan dukungan segenap komponen masyarakat dalam mendorong terwujudnya iklim yang kondusif bagi tumbuh dan berkembangnya kepariwisataan di suatu destinasi atau wilayah.

Pengertian lainnya dari kelompok sadar wisata (Pokdarwis) adalah kelembagaan di tingkat masyarakat yang anggotanya terdiri dari para pelaku kepariwisataan yang memiliki kepedulian dan tanggung jawab serta berperan sebagai penggerak dalam mendukung terciptanya iklim kondusif bagi tumbuh dan berkembangnya kepariwisataan serta terwujudnya Sapta Pesona dalam meningkatkan pembangunan daerah melalui kepariwisataan dan manfaatnya bagi kesejahteraan masyarakat sekitar.

Pokdarwis ini merupakan kelompok swadaya dan swakarsa masyarakat yang dalam aktivitas sosialnya berupaya untuk:

- Meningkatkan

pemahaman kepariwisataan.

- Meningkatkan peran dan partisipasi masyarakat dalam pembangunan kepariwisataan.

- Meningkatkan nilai manfaat kepariwisataan bagi masyarakat/ anggota Pokdarwis.

- Menyukseskan kepariwisataan.

Tujuan dari pembentukan kelompok sadar wisata (Pokdarwis) ini adalah sebagai berikut: 1) Meningkatkan posisi dan peran masyarakat sebagai subjek atau pelaku penting dalam pembangunan kepariwisataan, serta dapat bersinergi dan bermitra dengan pemangku kepentingan terkait dalam meningkatkan kualitas perkembangan kepariwisataan di daerah; 2) Membangun dan menumbuhkan sikap dan dukungan positif masyarakat sebagai tuan rumah melalui perwujudan nilai-nilai Sapta Pesona bagi tumbuh dan berkembangnya kepariwisataan di daerah dan manfaatnya bagi pembangunan daerah maupun kesejahteraan masyarakat; 3) Memperkenalkan, melestarikan, dan memanfaatkan potensi daya tarik wisata yang ada di masing-masing daerah.

\section{METODE PENELITIAN}

Penelitian ini menggunakan metode kualitatif, penelitian deskriptif ditujukan untuk mendeskripsikan atau menggambarkan fenomena-fenomena yang ada, baik fenomena yang bersifat alamiah ataupun rekayasa manusia (Sukmadinata, 2012). Menurut Rakhmat (2005), penelitian deskriptif hanya memaparkan situasi atau peristiwa. Penelitian deskriptif tidak mencari atau menjelaskan hubungan, tidak menguji hipotesis atau membuat prediksi.

Metode deskriptif dipergunakan karena peneliti bermaksud menggambarkan fenomena-fenomena sosial yang terjadi saat penelitian dilakukan, yaitu mengenai hal-hal yang berhubungan dengan Program Pembinaan Kelompok Sadar Wisata di Situ Pengasinan oleh Dinas Pemuda Olahraga Pariwisata Seni dan Budaya Kota Depok.

Penelitian ini menggunakan paradigma positivistik. Positivistik merupakan aliran yang berakar pada paham ontologi realisme yang menyatakan bahwa realitas berada (exist) dalam kenyataan dan berjalan sesuai dengan hukum alam. Penelitian menggunakan paradigma positivistik ini berupaya untuk mengungkapkan kebenaran realitas yang ada dan bagaimana realitas tersebut senyatanya berjalan (Salim, 2006). 
Penentuan informan kunci dilakukan dengan teknik purposive sampling, dimana purposive sampling merupakan teknik pengambilan sampel sumber data dengan pertimbangan tertentu (Sugiyono, 2011). Peneliti menentukan beberapa informan kunci yang memenuhi kriteria yang sudah peneliti tentukan dengan pertimbangan tertentu.

Teknik pengumpulan data yang dilakukan adalah observasi, wawancara, dan studi pustaka. Peneliti menggunakan analisis data Model Miles dan Huberman yang terdiri dari data reduction, data display, dan conclusion drawing/verification (Sugiyono, 2011).

Teknik validitas yang digunakan dalam penelitian ini adalah triangulasi. Triangulasi dalam pengujian kredibilitas ini diartikan sebagai pengecekan data dari berbagai sumber dengan berbagai cara dan berbagai waktu (Sugiyono, 2011). Peneliti menggunakan triangulasi sumber dimana peneliti mewawancarai sumber lain untuk melihat kebenaran informasi yang disampaikan oleh informan. Triangulasi sumber untuk menguji kredibilitas data dilakukan dengan cara mengecek data yang telah diperoleh melalui beberapa sumber.

\section{HASIL PENELITIAN DAN PEMBAHASAN}

Peran komunikasi sangat dibutuhkan
dalam berbagai bidang kehidupan
termasuk dalam kegiatan pemberdayaan
masyarakat dalam upaya pembangunan
Kota Depok. Jika dilihat dari persepsi
bidang komunikasi,
pemberdayaan masyarakat ini termasuk
dalam bidang komunikasi pembangunan
yang tujuannya bukan hanya mengubah
sikap, pendapat, dan perilaku tapi juga
bertujuan untuk mengubah masyarakat
yakni kemandirian masyarakat Kota
Depok dalam mengelola objek wisata situ.
Menurut Effendy (2000), tujuan
komunikasi adalah a) mengubah sikap (to

change the attitude), b) mengubah opini/pendapat/pandangan (to change the opinion), c) mengubah perilaku (to change the behavior), d) mengubah masyarakat (to change the society).

Saat ini Kota Depok hanya memiliki 22 situ dari total 28 situ yang ada, hal ini disebabkan sebagian situ ada yang hilang karena tidak dirawat, sehingga terjadi pedangkalan dan adapula yang sudah beralih fungsi dijadikan bangunan untuk permukiman warga. Pengalihan fungsi situ dan pembangunan baik untuk permukiman maupun kepentingan lainnya di atas lahan situ menjadi isu yang mengawatirkan. Berbagai kepentingan pribadi dan ketidakpedulian terhadap situ yang bisa menjadi aset pariwisata Kota Depok telah menyebabkan beberapa situ tidak bisa dipertahankan dan akhirnya hilang. Hal ini tentu dapat bertambah jika beberapa situ yang masih ada juga tidak dirawat. Padahal, jika dilihat dari jumlah situ yang ada di Kota Depok, bisa menjadi salah satu alternatif potensi objek wisata. Untuk itu Disporaparsenbud Kota Depok merasa perlu untuk melestarikan situ dengan melakukan pemberdayaan masyarakat dengan membuat Program Pembinaan Kelompok Sadar Wisata.

Kelompok sadar wisata ini merupakan komunitas yang bersinergi dalam pembangunan kepariwisataan. Komunitas adalah sekumpulan individu yang mendiami lokasi tertentu dan biasanya terkait dengan kepentingan bersama (Iriantara, 2004). Kelompok Sadar Wisata merupakan masyarakat yang tinggal di sekitar daerah wisata dan memiliki mata pencaharian dalam bidang penyediaan barang atau jasa yang berkaitan bagi kebutuhan wisatawan yang secara sukarela mau berpartisipasi dan memberikan dukungan demi terwujudnya iklim yang kondusif bagi tumbuh berkembangnya kepariwisataan di suatu destinasi pariwisata.

Program Pembinaan Kelompok Sadar Wisata yang dilaksanakan oleh Disporaparsenbud Kota Depok bertujuan 
untuk pembangunan kepariwisataan dengan berbasiskan pemberdayaan masyarakat. Pemberdayaan masyarakat (community empowerment) merupakan ruang lingkup dari community development bertujuan memperlihatkan bagaimana anggota masyarakat dapat mengaktualisasikan diri mereka dalam pengelolaan lingkungan yang ada di sekitarnya dan memenuhi kebutuhan secara mandiri tanpa ketergantungan dengan pihak-pihak lain, dan tentunya dengan menggunakan dasar budaya yang telah diterima secara turun temurun (Rudito \& Famiola, 2013).

Berdasarkan Peraturan Daerah Kota Depok Nomor 16 Tahun 2013 tentang Kepariwisatan, setiap destinasi pariwisata dapat dibentuk kelompok sadar wisata yang terdiri dari masyarakat yang bertempat tinggal di sekitar lokasi objek wisata. Untuk saat ini di Kota Depok baru membentuk kelompok sadar wisata di objek wisata situ. Pembentukan kelompok wisata di situ-situ ini karena pada awalnya masyarakat di sekitar situ merasa peduli terhadap situ yang memiliki fungsi untuk menanggulangi banjir. Kemudian Dinas Pemuda Olahraga Pariwisata Seni dan Budaya Kota Depok melantik kelompok sadar wisata yang sudah ada dan melakukan pembinaan kepada anggota kelompok sadar wisatanya.

Kota Depok telah melaksanakan Program Pembinaan Kelompok Sadar Wisata ini sejak tahun 2014 setelah dikeluarkannya Peraturan Daerah Kota Depok Nomor 16 Tahun 2013 tentang Kepariwisataan (Pemerintah Daerah Kota Depok, 2013b), dan di dalam Bab IX Pasal 53 ayat (1) dan (2) disampaikan bahwa setiap destinasi wisata dapat dibentuk Kelompok Sadar Wisata yang terdiri dari unsur masyarakat yang bertempat tinggal di sekitar lokasi daya tarik wisata dan memiliki kepedulian terhadap pengembangan kepariwisataan. Program Pembinaan Kelompok Sadar Wisata di Kota Depok, dilaksanakan dengan membentuk dan melantik kelompok sadar wisata yang ada di situ-situ yang terpilih, kemudian barulah dilakukan pembinaan. Pembinaan pokdarwis di sepuluh situ tersebut dimaksudkan agar Pokdarwis dapat mengelola objek wisata dan nantinya akan membuat objek wisata situ tersebut menjadi lebih maju dan lebih bagus baik dari segi kebersihan, keamanan, serta daya dukung objek wisata lainnya. Komunikasi memiliki peran yang sangat penting dalam melakukan pembinaan, dan fungsi komunikasi dalam pembinaan terhadap anggota pokdarwis adalah mendidik (to educate).

Program Pembinaan Kelompok Sadar Wisata ini dapat dikategorikan sebagai salah satu bentuk community empowerment dari Disporaparsenbud Kota Depok. Rudito \& Famiola (2013) mengemukakan bahwa community empowerment atau pemberdayaan masyarakat merupakan program-program yang berkaitan dengan memberikan akses yang lebih luas kepada masyarakat untuk menunjang kemandiriannya. Hal tersebut yang dilakukan oleh Disporaparsenbud Kota Depok dalam program ini, Disporaparsenbud Kota Depok memberikan akses secara luas kepada masyarakat yang ada di sekitar wilayah situ untuk mengelola objek wisata situ secara mandiri. Dalam pelaksanaan kegiatan community empowerment dibutuhkan tahapan-tahapan agar kegiatan ini bisa berjalan sesuai dengan target dan mencapai tujuannya yaitu kemandirian masyarakat demi tercapai kesejahteraan masyarakat.

Tahapan awal dalam kegiatan pemberdayaan masyarakat ini adalah seleksi lokasi/wilayah. Seleksi wilayah dilakukan untuk memilih lokasi mana yang cocok untuk diberikan kegiatan pemberdayaan masyarakat. Menurut Delivery dalam Mardikanto \& Soebiato (2012), seleksi wilayah dilakukan sesuai dengan kriteria yang disepakati oleh lembaga, pihak-pihak terkait, dan masyarakat. Penetapan kriteria penting agar pemilihan lokasi dilakukan sebaik 
mungkin, sehingga tujuan pemberdayaan masyarakat akan tercapai seperti yang diharapkan. Hal ini pula yang dilakukan oleh Disporaparsenbud Kota Depok sebelum merumuskan program, Disporaparsenbud terlebih dahulu memetakan situ-situ yang kelompok sadar wisatanya akan dibina, mencari data mengenai kondisi objek wisata situ, kirakira potensi pariwisata apa yang ada di wilayah tersebut, bagaimana daya dukungnya, apa yang bisa diterapkan di sana, dan apa yang dibutuhkan oleh objek wisata tersebut, kemudian barulah melakukan pemberdayaan dan pemandirian terhadap anggota kelompok sadar wisata dari situ-situ tersebut. Menurut Delivery dalam Mardikanto \& Soebiato (2012), tahapan-tahapan kegiatan pemberdayaan masyarakat tersebut meliputi seleksi lokasi, sosialisasi pemberdayaan masyarakat, proses pemberdayaan masyarakat, dan pemandirian masyarakat. Komunikasi memegang peranan penting dalam kegiatan pemberdayaan masyarakat, di mana fungsi komunikasi berperan dalam setiap tahapannya.

Program Pembinaan Kelompok Sadar Wisata ini dalam melakukan seleksi lokasi, Disporaparsenbud Kota Depok tidak memiliki kriteria khusus sehingga terpilihlah sepuluh situ dan kelompok sadar wisatanya yang akhirnya dilantik dan dibina. Tidak ada kriteria khusus terhadap pemilihan lokasi dalam Program Pembinaan Kelompok Sadar Wisata, hanya saja kriteria yang terpenting adalah situ tersebut mampu memberikan retribusi. Menurut Peraturan Daerah Kota Depok Nomor 07 Tahun 2013 Tentang Retribusi Pemakaian Kekayaan Daerah (Pemerintah Daerah Kota Depok, 2013a), menyatakan bahwa retribusi merupakan pungutan daerah sebagai pembayaran atas jasa atau pemberian izin tertentu yang khusus disediakan dan/atau diberikan oleh pemerintah daerah untuk kepentingan orang pribadi atau badan. Dengan adanya retribusi dari objek wisata diharapkan kelompok sadar wisata mampu untuk mengelola objek wisata tersebut, hal ini pulalah yang menjadi potensi dari situ tersebut, di samping potensi objek wisata harus memiliki wilayah strategis, adanya akses menuju objek wisata tersebut, Pokdarwisnya aktif serta adanya sarana dan prasarana penunjang objek wisata serta adanya daya tarik wisata. Daya tarik wisata merupakan potensi yang menjadi pendorong kehadiran wisatawan ke suatu daerah tujuan wisata atau dapat dikatakan sebagai segala sesuatu yang memiliki keunikan, kemudahan, dan nilai yang berupa keanekaragaman kekayaan alam, budaya, dan hasil buatan manusia yang menjadi sasaran atau kunjungan wisatawan, dalam hal ini adalah objek situ yang merupakan wisata alam. Retribusi, sarana, dan prasarana serta daya tarik wisata merupakan kriteria dalam penentuan lokasi wisata. "Penetapan kriteria penting agar pemilihan lokasi dilakukan sebaik mungkin, sehingga tujuan pemberdayaan masyarakat akan tercapai seperti yang diharapkan" (Mardikanto \& Soebiato, 2012). Tidak adanya kriteria khusus ini disebabkan tujuan dari program ini adalah untuk mengembangkan seluruh pariwisata situ di Kota Depok, sehingga situ-situ lainnya yang belum terpilih akan mendapatkan program yang sama di waktu mendatang.

Kriteria dalam seleksi lokasi atau wilayah yang ditentukan oleh Disporaparsenbud Kota Depok dalam Program Pembinaan Pokdarwis sebagai program pembangunan kepariwisataan berbasis pemberdayaan masyarakat sesuai dengan yang tercantum dalam UndangUndang No. 9 Tahun 1990 tentang Kepariwisataan (Republik Indonesia, 1990). Dalam udang-undang tersebut dinyatakan bahwa unsur pokok yang harus mendapatkan perhatian guna menunjang pengembangan pariwisata di daerah tujuan wisata yang menyangkut perencanaan, pelaksanaan pembangunan, dan pengembangannya meliputi lima unsur, yaitu objek dan daya tarik wisata, 
prasarana wisata, sarana wisata, infrastruktur, dan masyarakat atau lingkungan.

Berdasarkan hasil wawancara dan observasi, maka dapat diketahui beberapa hal yang menjadi pertimbangan Disporaparsenbud dalam melakukan seleksi lokasi sehingga tercipta kriteria yang menghasilkan sepuluh situ yang ada di Kota Depok untuk dibina dalam Program Pembinaan Kelompok Sadar Wisata. Kriteria tersebut adalah adanya retribusi dan potensi objek wisata, potensi objek wisata meliputi wilayah yang strategis, adanya daya tarik wisata, adanya sarana dan prasarana penunjang objek wisata, kemudahan aksesibilitas, serta kelompok sadar wisata yang aktif. Unsurunsur tersebut perlu diperhatikan dalam pengembangan pariwisata di suatu daerah tujuan wisata.

Kegiatan

kepariwisataan, melibatkan peran dari tiga pemangku kepentingan yaitu pemerintah, swasta, dan masyarakat. Masyarakat menjadi salah satu unsur penting untuk bersama-sama dengan pemerintah dan swasta melaksanakan dan mendukung pembangunan kepariwisataan. Menurut Kementerian Pariwisata dan Ekonomi Kreatif (2012), peran pemerintah dalam pembangunan kepariwisataan adalah sebagai fasilitator dan pembuat peraturan (regulator). Kalangan swasta atau para pelaku usaha, dengan segala sumber daya, modal, dan jejaring yang dimilikinya, berperan sebagai pengemban dan pelaksana pembangunan kegiatan kepariwisataan. Sedangkan masyarakat dengan sumber daya yang dimilikinya, baik berupa adat, tradisi, dan budaya, serta kapasitasnya sebagai tuan rumah, memiliki kesempatan sebagai pelaku pengembangan kepariwisataan sesuai dengan kemampuan yang dimilikinya.

Keterlibatan ketiga pemangku kepentingan berlaku pula pada Program Pembinaan Kelompok Sadar Wisata yang dilaksanakan oleh Disporaparsenbud Kota
Depok. Sebagai suatu program yang bertujuan untuk pembangunan kepariwisataan dengan berbasiskan pemberdayaan masyarakat. Pihak-pihak yang terlibat dalam Program Pembinaan Kelompok Sadar Wisata ini yaitu pemerintah, swasta, dan masyarakat. Pemerintah yang dimaksud adalah Disporaparsenbud Kota Depok dan juga Pemerintah Kota Depok sebagai fasilitator yang memberikan bantuan untuk pembangunan sarana dan prasarana objek wisata serta memberikan pembinaan terkait dengan pengelolaan objek wisata. Dalam proses pembinaan pihak Disporaparsenbud Kota Depok memberikan pelayanan informasi kepada para pemangku kepentingan. Winkel \& Hastuti (2006) menjelaskan bahwa layanan informasi adalah usaha untuk membekali seseorang dengan pengetahuan tentang data dan fakta di bidang tertentu, supaya mereka bisa belajar tentang lingkungan hidupnya lebih mampu mengatur dan merencanakan kehidupannya sendiri. Anggota Pokdarwis dibina supaya mereka mampu mengelola objek wisata situ dengan baik. Adapun pihak swasta dalam hal ini para pelaku usaha memiliki modal dan jejaring sosial yang cukup besar baik dalam bidang jasa travel, hotel, dan penginapan, serta rumah makan, sehingga bisa mendirikan usaha-usaha di dekat objek wisata yang menambah minat wisatawan untuk berkunjung, masyarakat dalam hal ini adalah anggota kelompok sadar wisata yang ada di objek wisata situsitu yang ada di Kota Depok. Kesepuluh kelompok sadar wisata ini merupakan penerima manfaat dari Progam Pembinaan Kelompok Sadar Wisata Kota Depok yang telah melewati tahapan seleksi lokasi/wilayah.

Berdasarkan uraian di atas, terlihat jelas relasi antara para pemangku kepentingan dalam kegiatan pembangunan kepariwisataan.

Pemerintah tidak dapat mengembangkan objek wisata jika tidak ada peran dari swasta yang memiliki 
modal yang cukup besar dan masyarakat yang berperan dengan terjun langsung mengelola objek wisata.

Kemudian swasta tidak dapat membangun pariwisata jika tidak ada izin dari pemerintah yang merupakan regulator dalam kegiatan pembangunan kepariwisataan dan masyarakat sekitar lokasi objek wisata yang kuat akan adat, tradisi, dan budaya. Selain itu masyarakat sebagai tuan rumah tidak dapat pula mengembangkan suatu objek pariwisata tanpa adanya bantuan pemerintah sebagai fasilitator dan para pelaku usaha yang merupakan pihak swasta.

Konteks komunikasi dalam kegiatan ini adalah konteks komunikasi kelompok dan komunikasi antarpribadi. Kelompok adalah sekumpulan orang yang mempunyai tujuan yang sama, yang berinteraksi satu sama lain untuk mencapai tujuan bersama, mengenal satu sama lainnya, dan memandang mereka sebagai bagian dari kelompok tersebut. Komunikasi kelompok dengan sendirinya melibatkan juga komunikasi antarpribadi (Mulyana, 2001).

Dalam melaksanakan pemberdayaan masyarakat melalui Program Pembinaan Kelompok Sadar Wisata. Disporapaesenbud Kota Depok telah melibatkan tiga pemangku kepentingan, dan proses pemberdayaan tersebut dilaksanakan melalui proses dialog dan interaksi, namun dalam menentukan kriteria untuk seleksi lokasi, Disporaparsenbud Kota Depok tanpa membuat kesepakatan terlebih dahulu dengan pelaku usaha pariwisata dan Pokdarwis, padahal dengan adanya kesepakatan mengenai kriteria ini akan timbul kesepahaman antara Pokdarwis di 22 situ yang ada di Kota Depok dengan Disporaparsenbud terkait dengan pemilihan 10 situ yang mendapatkan Program Pembinaan Kelompok Sadar Wisata sehingga situ-situ yang lain dapat meningkatkan kualitasnya untuk mencapai kualifikasi atau kriteria yang ditetapkan oleh Disporaparsenbud Kota Depok.

\begin{tabular}{|c|c|c|}
\hline $\begin{array}{c}\text { Kriteria Objek } \\
\text { Wisata } \\
\text { Berbotensi }\end{array}$ & $\begin{array}{c}\text { Pemangku } \\
\text { Kepentingan }\end{array}$ & $\begin{array}{c}\text { Objek Wisata } \\
\text { Terpilih }\end{array}$ \\
\hline $\begin{array}{l}\text { 1. Retribusi } \\
\text { - } \text { Situ mampu } \\
\text { memberikan } \\
\text { retribusi } \\
\text { 2. Potensi } \\
\text { - Wilayah objek } \\
\text { wisata } \\
\text { - } \text { situ strategis } \\
\text { - Kelompok sadar } \\
\text { wisata yang aktif } \\
\text { - Ada akses menuju } \\
\text { objek wisata situ } \\
\text { - Ada daya tarik } \\
\text { wisata } \\
\text { - Ada sarana dan pra } \\
\text { sarana penunjang } \\
\text { objek wisata. }\end{array}$ & 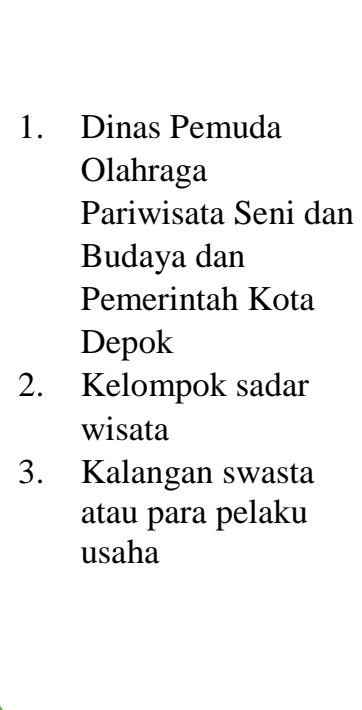 & $\begin{array}{ll}\text { 1. } & \text { Situ Sawangan } \\
\text { 2. } & \text { Situ Jatijajar } \\
\text { 3. } & \text { Situ Sidamukti } \\
\text { 4. } & \text { Situ Pedongkelan } \\
\text { 5. } & \text { Situ Pulo Asih } \\
\text { 6. } & \text { Situ Cilodong } \\
\text { 7. } & \text { Situ Lio } \\
\text { 8. } & \text { Situ Citayem } \\
\text { 9. } & \text { Situ Cilangkap } \\
\text { 10. } & \text { Situ Pengasinan }\end{array}$ \\
\hline
\end{tabular}

Sumber: Olahan penulis

Gambar 1. Seleksi Lokasi/Wilayah Program Pembinaan Kelompok Sadar Wisata 


\section{PENUTUP}

\section{Simpulan}

Seleksi lokasi/wilayah dilakukan oleh Dinas Pemuda Olahraga Pariwisata Seni dan Budaya Kota Depok sudah dilakukan dengan baik, namun dalam menentukan kriteria belum ada kriteria khusus. Berdasarkan hasil penelitian, situsitu tersebut dipilih karena memiliki retribusi dan potensi. Kriteria dalam seleksi lokasi atau wilayah yang diberikan oleh Dinas Pemuda Olahraga Pariwisata Seni dan Budaya Kota Depok dalam Program Pembinaan Kelompok Sadar Wisata sebagai program pembangunan kepariwisataan berbasis pemberdayaan masyarakat dapat dikatakan sesuai dengan dalam Undang-Undang No. 9 Tahun 1990 tentang Kepariwisataan, sayangnya Dinas Pemuda Olahraga Pariwisata Seni dan Budaya Kota Depok tidak mengadakan dialog awal dengan tiga pemangku kepentingan dalam pembangunan pariwisata, yaitu pemerintah, swasta, dan masyarakat untuk membuat kesepakatan terkait pembentukan kriteria dalam pemilihan lokasi/wilayah dalam Program Pembinaan Kelompok Sadar Wisata.

Konteks komunikasi dari proses seleksi lokasi/wilayah ini tergolong ke dalam konteks komunikasi kelompok dan komunikasi antarpribadi. Masyarakat menjadi salah satu unsur penting untuk bersama-sama dengan pemerintah dan swasta melaksanakan dan mendukung pembangunan kepariwisataan. Peran pemerintah dalam pembangunan kepariwisataan adalah sebagai fasilitator dan pembuat peraturan (regulator). Kalangan swasta atau para pelaku usaha, dengan segala sumber daya, modal, dan jejaring yang dimilikinya, berperan sebagai pengemban dan/atau pelaksana pembangunan kegiatan kepariwisataan. Sedangkan masyarakat dengan sumber daya yang dimilikinya, baik berupa adat, tradisi dan budaya, serta kapasitasnya sebagai tuan rumah, memiliki kesempatan sebagai pelaku pengembangan kepariwisataan sesuai dengan kemampuan yang dimilikinya.

\section{Saran}

Dinas Pemuda Olahraga Pariwisata Seni dan Budaya Kota Depok sebaiknya menetapkan kriteria khusus pemilihan lokasi/wilayah yang mendapatkan Program Pembinaan Kelompok Sadar Wisata dengan membuat kesepakatan bersama antara pihak swasta dan masyarakat khususnya kelompok sadar wisata. Adanya kriteria khusus ini bertujuan agar Program Pembinaan Kelompok Sadar Wisata dapat tepat sasaran dan tercapai sesuai dengan yang diharapkan.

Tercapainya kesepakatan dengan pihak-pihak terkait dapat menjadi salah satu motivasi bagi kelompok sadar wisata situ lainnya untuk mengelola objek wisata situ sehingga masuk dalam kualifikasi situ yang layak mendapatkan Program Pembinaan Kelompok Sadar Wisata agar di masa mendatang dapat meningkatkan kesejahteraan masyarakat di sana.

Dinas Pemuda Olahraga Pariwisata Seni dan Budaya Kota Depok sebaiknya melakukan Komunikasi Partisipatoris dalam seleksi lokasi/wilayah sehingga terjalin komunikasi dua arah dan kelompok sadar wisata dilibatkan dalam proses awal program pembinaan ini.

\section{DAFTAR PUSTAKA}

Depoktren (2014) Dikukukan Kelompok Sadar Wisata Setu. [Online]. 2014. Available from:

http://depoktren.com/2014/04/02/dikuku kan-kelompok-sadar-wisata-setu/ [Accessed: 28 October 2017].

Effendy, O.U. (2000) Teori Ilmu, and Filsafat Komunikasi. Bandung, Citra Aditya Bakti.

Irawan, E.P. (2013) Program Corporate Social Responsibility Berbasis Pemberdayaan Masyarakat. [Online]. Universitas Padjadjaran. Available from: http://repository.unpad.ac.id/17584/. 
Iriantara, Y. (2004) Community Relations: Konsep dan Aplikasinya. Bandung, Simbiosa Rekatama Media.

Kementerian Pariwisata dan Ekonomi Kreatif (2012) Pedoman Kelompok Sadar Wisata. [Online]. Jakarta, Direktur Jenderal Pengembangan Destinasi Pariwisata Kementerian Pariwisata dan Ekonomi Kreatif. Available from: http://www.kemenpar.go.id/userfiles/1_ Pedoman Pokdarwis.pdf.

Mardikanto, T. \& Soebiato, P. (2012) Pemberdayaan Masyarakat Dalam Perspektif Kebijakan Publik. Bandung, Alfabeta.

Mulyana, D. (2001) Pengantar Ilmu Komunikasi. Bandung, Remaja Rosdakarya.

Pemerintah Daerah Kota Depok (2013a) Peraturan Daerah Kota Depok Nomor 07 Tahun 2013 Tentang Perubahan Atas Peraturan Daerah Kota Depok Nomor 08 Tahun 2011 Tentang Retribusi Pemakaian Kekayaan Daerah.

Pemerintah Daerah Kota Depok (2013b) Peraturan Daerah Kota Depok Nomor 16 Tahun $2013 \quad$ Tentang Kepariwisataan.

Rakhmat, J. (2005) Metode Penelitian Komunikasi. Bandung, Remaja Rosdakarya.

Republik Indonesia (1990) Undang Undang Nomor 9 Tahun 1990 Tentang Kepariwisataan.
Rudito, B. \& Budimanta, A. (2003) Metode dan Teknik: Pengelolaan Community Development. Jakarta, ICSD (Indonesian Center for Sustainable Development).

Rudito, B. \& Famiola, M. (2013) CSR (Corporate Social Responsibility). Bandung, Rekayasa Sains.

Salim, A. (2006) Teori dan Paradigma Penelitian Sosial. Yogyakarta, Tiara Wacana.

Sari, P.T.L. (2014) Program Pemberdayaan Kontraktor Lokal Total E\&P Indonesie. [Online]. Universitas Padjadjaran. Available from: http://pustaka.unpad.ac.id/archives/1324 23.

Soekadijo, R.G. (2000) Anatomi Pariwisata. Jakarta, Gramedia Pustaka Utama.

Sugiyono (2011) Metode Penelitian Kuantitatif, Kualitatif, dan $R \& D$. Bandung, Alfabeta.

Suharto, E. (2010) CSR \& COMDEV Investasi Kreatif Perusahaan di Era Globalisasi. Bandung, Alfabeta.

Sukmadinata, N.S. (2012) Metode Penelitian Pendidikan. Bandung, Remaja Rosdakarya.

Winkel, W.S. \& Hastuti, M.M.S. (2006) Bimbingan dan Konseling di Institusi Pendidikan. Yogyakarta, Media Abadi. 